\title{
PRIORITIES OF IMPROVING THE COMPETITIVENESS OF HIGHER EDUCATION IN REGIONAL DEVELOPMENT MANAGEMENT (CASE OF UKRAINE)
}

http://doi.org/10.23939/semi2021.01.144

(C) Hrynkevych O., Sorochak O., 2021

Purpose. This article aims to test the hypothesis of significant imbalances in the regional higher education systems in Ukraine and to substantiate the priority areas for improving their competitiveness on the criteria of quality, social responsibility, and economic efficiency.

Design/methodology/approach. The first part of the study offers a conceptual model for analysing the higher education system's competitiveness. The authors use the main provisions of the theory of human, social and intellectual capital, stakeholder theory, literature review method, and interdisciplinary approach to determine the features of higher education as a particular sector of social activity, regional economy, as well as an object of competitiveness analysis in terms of three criteria quality, economic efficiency, and social responsibility. In the second part, the authors propose the methodological framework and list of indicators for analysing the regional higher education systems based on a developed conceptual model. The third part presents the results of statistical analysis of higher education systems in 25 regions of Ukraine and priority areas for improving their competitiveness by the criteria of quality, social responsibility, and economic efficiency.

Findings. The hypothesis of significant imbalances in the regional higher education systems in Ukraine is proven. The results of the analysis reveal substantial differences in the regional higher education systems, particularly for indicators as the ratio of university entrants and high school graduates participating in the independent external testing in this region, the proportion of HEIs students studying at the expense of local budgets, the number of regional HEIs in the world university rankings. Considering the results of the analysis and the features of regional development, the authors substantiate the priority areas for improving the competitiveness of the higher education system for Ukraine's regions by the criteria of quality, social responsibility, and economic efficiency. Each of these priority areas involves using appropriate target indicators and considers the interests of key stakeholders of the higher education system.

Practical implications. The authors propose priority areas for improving the competitiveness of higher education in the regions that can be used to implement the strategic goals of the potential intellectual development of Ukraine's regions and thus enhance the role of HEIs in solving urgent problems of regional development.

Originality/value. Despite numerous papers on economics and management in higher education, there are virtually no studies in academic practice, which aim to take into account the regional features of higher education. Secondly, based on its comprehensive empirical research, third, 
Priorities of improving the competitiveness of higher education in regional development management...

it can justify the strategic priorities for the development of provincial higher education systems with relevant target indicators. Thus this study aims to fill these gaps.

Key words: higher education; competitiveness; governance; quality; social responsibility; economic efficiency; region; Ukraine.

Paper type: Research paper.

\section{Formulation of the problem}

Global processes and challenges of the 21st century, including the Covid 19 pandemic, new forms of employment and population migration, accelerated digitalization, have set new strategic objectives for higher education (HE) systems worldwide.

These processese consequences are especially significant for post-Soviet countries' national security towards integration into the European educational and scientific space. Ukraine is one such country. On the one hand, Ukraine is reforming its HE system by adopting international quality standards; on the other hand, and it is experiencing significant losses due to military conflicts, educational and labor migration.

According to the UNESCO Institute for Statistics [17], the number of outbound internationally mobile students from Ukraine increased from 35.316 to 72.063 for 2010-2018. The Top 5 countries where Ukrainian youth migrates the most include neighboring nations with a higher quality of life standards and higher incomes. According to a survey of international students in Poland [4], these reasons motivate most Ukrainian youth to stay abroad after studying abroad.

Imbalances in the regions' social and economic development, including in HE, lead to human and intellectual resources loss. These problems are especially relevant for border regions, as well as areas with difficult environmental situations. The factors above and several other social and economic issues related to regional HE systems emphasize the importance of a comprehensive analysis and identification of ways to increase HE competitiveness.

\section{Analysis of recent research and publications}

Numerous scientific papers are devoted to HE's competitiveness, social and economic efficiency at the macro and microlevels. P. Altbach, L. Rumbley, D. Stanfield in [1], emphasize that HE became an object of economic sciences in the second half of the XX century, is not characterized by a clearly defined "central" research methodology and, due to the combination of socio-cultural and economic functions, requires an interdisciplinary approach to solving the problems of competitiveness improving. Ukrainian (O. Grishnova, S. Bekh [7]; O. Karyy, L. Halkiv [9]; I. Moyseyenko [12]; L. Shevchenko [14], and foreign (P. Altbach [1], A. Kisiołek [9], T. McCowan [11]; U. Teichler [15]) researchers of HE define interdisciplinarity, a combination of methodological tools of economics, sociology, management, and psychology as a scientific basis for analysing its competitiveness.

British researcher Tristan McCowan, studying the evolution of the university as the primary institutional form of higher education according to the criteria of values, functions, and forms of interaction with society in (Multiversity, Enterprise). These models are characterized by different degrees of implementation of educational, research, and social functions and the possibility of their performance, depending on the level of socio-economic development of each country.

Studying the development of higher education systems, Ukrainian researcher L. Shevchenko in [14] defines the area of responsibility of state institutions in higher education. This is, first of all, the improvement of educational law, the development of strategies and policies for the development of higher education, taking into account the transformation of the information society into a knowledge society.

Despite numerous papers on economics and management in higher education in Ukraine, there are virtually no studies [11], distinguishes five models of the university (Medieval, Humboldtian, Developmental, in academic practice, which, firstly, are aimed at taking into account the regional features of higher education, and secondly, based on its comprehensive empirical research, third, can be used to justify the strategic priorities for the development of regional higher education systems with a list of relevant target indicators. 


\section{O. Hrynkevych, O. Sorochak}

\section{Formulating hypotheses and setting objectives}

The purpose of this study is to test the hypothesis of significant imbalances in the regional higher education systems in Ukraine and to develop the priority areas for improving their competitiveness by the criteria of quality, social responsibility, and economic efficiency.

\section{Research methods}

The first part of the study offers a conceptual model for analysing the higher education system's competitiveness. The authors use the main provisions of the theory of human, social and intellectual capital, stakeholder theory, literature review method, and systematic approach to determine the features of higher education as a particular sector of social activity, regional economy, as well as an object of competitiveness analysis in terms of three criteria - quality, economic efficiency, and social responsibility. In the second part, the authors propose the methodological framework and list of indicators for analysing the regional higher education systems based on the developed conceptual model. The third part presents the results of the statistical analysis of higher education systems in 25 regions of Ukraine and priority areas for improving their competitiveness by the criteria of quality, social responsibility, and economic efficiency. The empirical part of the study is based on the State Statistics Service of Ukraine, the Ministry of Education and Science of Ukraine, the Ukrainian Center for Educational Quality Assessment, and regional authorities' official websites.

\section{Main part}

Higher education is a particular sector of social activity and regional economy. Firstly, according to classical works and contemporary studies (e.g., Altbach [1], McCowan [11], Teichler [15]) this sector is crucial in the development of human, social and intellectual capital. The second characteristic is the generation of new knowledge and skills that result from HE institutions' activity (HEIs) and provide not only benefits in the labor market but also shape the innovation potential of economic growth in other sectors of the economy. The third characteristic is related to a set of HE's general and specific functions (Table 1).

\section{Table 1}

\section{Relationship between general and specific functions of higher education}

\begin{tabular}{|c|c|c|c|c|}
\hline & & \multicolumn{3}{|c|}{ Specific functions of higher education } \\
\hline & & Teaching & Research & Public services \\
\hline \multirow{3}{*}{ 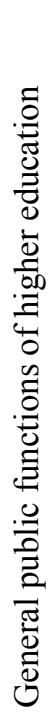 } & Social & $\begin{array}{l}\text { Development of social } \\
\text { capital through social } \\
\text { interaction and intercultural } \\
\text { communication }\end{array}$ & $\begin{array}{l}\text { Generation of new ideas, } \\
\text { knowledge that are } \\
\text { implemented into social } \\
\text { innovations and provide } \\
\text { social security }\end{array}$ & $\begin{array}{l}\text { Implementation of the } \\
\text { ideas of responsibility in } \\
\text { the socio-cultural, } \\
\text { ecological spheres of } \\
\text { society }\end{array}$ \\
\hline & Economic & $\begin{array}{l}\text { Development of intellectual } \\
\text { capital, which ensures } \\
\text { competitiveness in the labor } \\
\text { market }\end{array}$ & $\begin{array}{l}\text { Generation of ideas that } \\
\text { are implemented into } \\
\text { innovations and provide } \\
\text { the economy's } \\
\text { competitiveness }\end{array}$ & $\begin{array}{l}\text { Implementation of the } \\
\text { ideas of social } \\
\text { responsibility in the } \\
\text { economic sphere of } \\
\text { society }\end{array}$ \\
\hline & Political & $\begin{array}{l}\text { Development of leadership } \\
\text { skills that provides for the } \\
\text { formation of the society's } \\
\text { political elite }\end{array}$ & $\begin{array}{l}\text { Generation of new } \\
\text { knowledge that provides } \\
\text { security at the level of } \\
\text { national, regional and } \\
\text { local political systems }\end{array}$ & $\begin{array}{l}\text { Critical comprehension } \\
\text { and public discussion of } \\
\text { social issues and politics. } \\
\text { Development of civil } \\
\text { society institutions }\end{array}$ \\
\hline
\end{tabular}

Source: developed by the authors. 
Priorities of improving the competitiveness of higher education in regional development management...

On the one hand, the unique features of $\mathrm{HE}$ as an object of analysis and competitiveness management are also related to the influence of state and regional regulatory institutions, on the one hand, and irrational behavior models on the educational services market.

The features defined above are essential for understanding the factors of HE competitiveness and its impact on the economic growth and sustainable development of the region and national security.

From the standpoint of an inter-disciplinary approach, we propose the definition of $\mathrm{HE}$ as a system of interconnected informal (values, ways of thinking, behavior, etc.) and formal (laws, standards, providers, stakeholders, etc.) institutions that provide an understanding of the critical role of knowledge in self-improvement, its storage, transmission, and generation of new knowledge for the implementation of individual and institutional development goals, as well as determine the intellectual potential and competitiveness of all spheres of a society's life.

The proposed definition provides outlines of the institutional architecture of the HE system, the identification of its components, including (Fig. 1): 1) formal and informal providers, 2) products, 3) internal and external stakeholders.

The external environment of the higher education system: external stakeholders

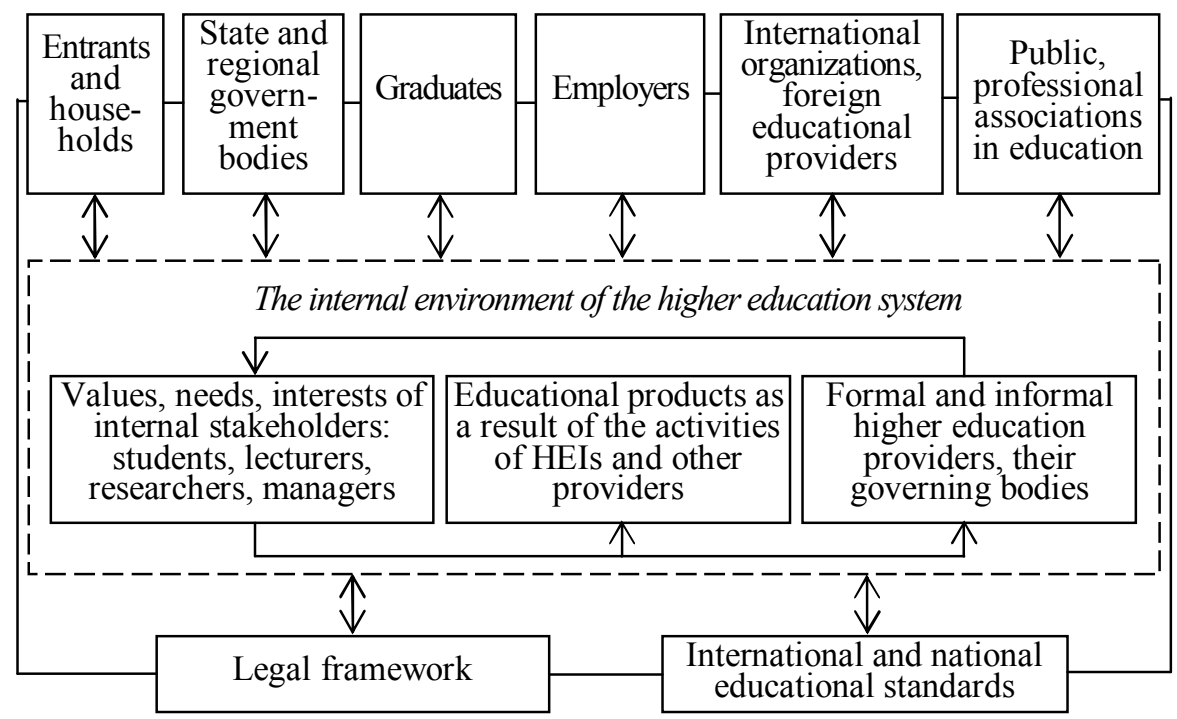

The external environment of the higher education system: institutions-norms

Fig. 1. Institutional architecture of the HE system

Source: developed by the authors.

The study of goals on the HE development, defined in particular by the Global Goals of Sustainable Development [21], the Incheon Declaration [20], shows that such goals have significant differences when it concerns their adaptation regional, the national level of the country's development. Simultaneously, summarizing the development goals related to the HE indicates that its global competitiveness can be interpreted as the function of three key variables - quality, social responsibility, and economic efficiency.

The author's conceptual model for analysis of the HE system competitiveness [8] is based on the following highlights:

1) providers, their products, and stakeholders are the main elements of the higher education system. Stakeholders' interests, the potential, and performance results (products) of providers form the basis of the model and are critical objects for institutional analysis;

2) quality, social responsibility, and economic efficiency are the critical criteria for institutional analysis of the higher education system competitiveness; 


\section{O. Hrynkevych, O. Sorochak}

3 ) it is advisable to develop different types of applied models of analysis, depending on the level of decision-making (local, regional, national) in higher education competitiveness management.

The proposed conceptual model makes it possible to substantiate methodological approaches to developing an analytical framework and determining factors of the higher education system's competitiveness at the regional level.

Indicators for competitiveness analysis of the regional higher education system. Based on a conceptual model for the HE analysis, we propose methodological approaches to competitiveness measurement according to three criteria - quality, social responsibility, and economic efficiency.

Taking into account international principles of quality management, the features of the HE system as a governance object, the needs of balancing interests of stakeholders, we offer a scheme for the quality analysis by the following criteria: 1) consumers' satisfaction (students, graduates, employers, etc.); 2) quality of the institutional environment; 3) quality of performance results in HE; 4) quality of suppliers (entrants, secondary education institutions, etc.).

Lists the indicators of the higher education system quality at the regional level, which also consider the peculiarities of its organization in Ukraine.

Table 2

Indicators of quality in competitiveness analysis of the region's HE system

\begin{tabular}{|l|l|}
\hline Analysis object & \multicolumn{1}{c|}{ Analysis indicators } \\
\hline $\begin{array}{l}\text { Consumers' } \\
\text { satisfaction }\end{array}$ & $\begin{array}{l}\text { Level of students' and graduates' satisfaction with the HE quality } \\
\text { Level of employers' satisfaction with the HE quality }\end{array}$ \\
\hline $\begin{array}{l}\text { Quality of the } \\
\text { institutional } \\
\text { environment }\end{array}$ & $\begin{array}{l}\text { Availability of institutions that monitor the HE quality } \\
\text { Number of lecturers and researchers per 10.000 inhabitants } \\
\text { Average age of lecturers and researchers in HEIs }\end{array}$ \\
\hline \multirow{4}{*}{ Performance results } & $\begin{array}{l}\text { Employment rate of HEIs graduates } \\
\text { Number and share of HEIs students - winners of international and national competitions } \\
\text { Number of patents per HEIs researcher } \\
\text { Number of HEIs in the world university rankings } \\
\text { Share of international students in HEIs } \\
\text { Number of works with international indexation per lecturer and researcher of HEIs }\end{array}$ \\
\hline & $\begin{array}{l}\text { Average / median grade of the document on secondary education of entrants / first-year } \\
\text { students of HEIs } \\
\text { Share of first-year students with the competitive score of 180 or higher at the External } \\
\text { Independent Testing Exam }\end{array}$ \\
\hline
\end{tabular}

Source: developed by the authors.

The indicators of the analysis of HE quality have different weights for particular stakeholder groups. In this regard, the proposed list can be used as a "set of possible indicators" to make decisions for improving the competitiveness of HE by quality criterion.

The generalization of theoretical and methodological approaches to understanding the essence of social responsibility of HEIs [7] as well as Guidance of International Organization for Standardization [5; 6], gives grounds to distinguish three types of classifications in the analysis of this object:

- the first type: areas of social responsibility: legal, social, economic, environmental;

- the second type: internal and external stakeholders who are interested in the fulfillment of HE goals;

- the third type: main activities in HE, which ensure its primary purposes and functions.

Considering the approaches mentioned above to understanding the content and levels of social responsibility, it is possible to define a set of indicators for measuring the HE system's competitiveness by the criterion of social responsibility (Table 3). 
Priorities of improving the competitiveness of higher education in regional development management...

In a broad sense, the higher education system is effective if it enhances the quality of life of its stakeholders, generates new knowledge, and ensures innovative development and competitiveness of business entities in the region of HEI activity. In a narrow sense, the HE system's economic efficiency can be measured through the ratio of financial results and assets of the system.

Summarizing methodological and applied approaches to the analytics of HE efficiency developed in the works of Brint and Clotfelter [2], Matyukh [9], Moyseyenko [12], we propose to use three types of economic efficiency indicators: 1) result indicators that reflect the activity of the HEIs in absolute terms; 2) performance indicators that make it possible to compare absolute indicators per unit of HEIs assets, student, etc.; 3) income diversification indicators that reflect the specific weight of income sources from various activities in total revenues of the HE system.

Table 3

Indicators of social responsibility in competitiveness analysis of the region's HE system

\begin{tabular}{|c|l|}
\hline \multicolumn{1}{|c|}{$\begin{array}{c}\text { Analysis object / } \\
\text { HE stakeholders }\end{array}$} & \multicolumn{1}{c|}{ Analysis indicators } \\
\hline \multirow{3}{*}{ Students } & $\begin{array}{l}\text { Number and share of students with disabilities and special needs } \\
\text { Number of the recorded facts of violations of students' rights } \\
\text { Number and share of students participating in projects related to regional } \\
\text { development } \\
\text { Number and share of students enrolled out of the funds of local budgets }\end{array}$ \\
\hline \multirow{2}{*}{$\begin{array}{l}\text { Lecturers, researchers } \\
\text { and HEI management }\end{array}$} & $\begin{array}{l}\text { Average salary in the region's HE system } \\
\text { Number of the reported facts of violations of the rights of lecturers and researchers } \\
\text { Number and share of lecturers and researchers involved in regional development } \\
\text { projects }\end{array}$ \\
\hline $\begin{array}{l}\text { Regional management } \\
\text { authorities }\end{array}$ & $\begin{array}{l}\text { Regional budget funds directed to the development of the region's higher education } \\
\text { Volume of the regional contract for the training in regional HEIs } \\
\text { Index of Regional Human Development }\end{array}$ \\
\hline
\end{tabular}

Source: developed by the authors.

Table 4 presents the system of indicators for monitoring the HE competitiveness by the criterion of economic efficiency.

Table 4

\section{Economic efficiency indicators in competitiveness analysis of the region's $\mathrm{HE}$ system}

\begin{tabular}{|l|l|}
\hline \multicolumn{1}{|c|}{ Analysis object } & \multicolumn{1}{c|}{ Analysis indicators } \\
\hline \multirow{3}{*}{ Results } & $\begin{array}{l}\text { Number of students per 10 thousand people of the region } \\
\text { Number and share of students studying under contract } \\
\text { Revenue of the region's HE system } \\
\text { Average salary of employees with HE }\end{array}$ \\
\hline & $\begin{array}{l}\text { Number of innovative enterprises in region } \\
\text { Share of innovative products in region }\end{array}$ \\
& $\begin{array}{l}\text { Unemployment rate among people with HE } \\
\text { Revenue of the region's HE system per unit of HEIs assets } \\
\text { Revenue of the region's HE system per employed in HEIs }\end{array}$ \\
\hline $\begin{array}{l}\text { Income } \\
\text { diversification }\end{array}$ & $\begin{array}{l}\text { Revenue share from educational activity in total revenues of the region's higher education } \\
\text { Revenue share from research activity in total revenues of the region's higher education } \\
\text { Revenue share of extra budgetary funds in total revenues of the region's higher education }\end{array}$ \\
\hline
\end{tabular}

Source: developed by the authors. 


\section{O. Hrynkevych, O. Sorochak}

Competitiveness analysis of the HE system involves not only the development of the indicators system, but also the use of reliable tools for measuring them, information and managers capable of achieving target indicators of competitiveness improvement. In this context Higher Education Reform Experts recommend to monitor only those indicators on which it is obligatory to make appropriate management decisions. The results of testing conceptual model for analysis indicate a significant asymmetry of regional HE systems by the competitiveness indicators. In the analysis of quality the most noticeable is the unequal distribution of Ukraine's regions by the level of international academic reputation of HEIs, in particular, their number in world university rankings (Table 5).

Table 5

Ukraine's HEIs and their scores in the World University Rankings (2018-2020)

\begin{tabular}{|c|c|c|}
\hline $\begin{array}{l}\text { Region of } \\
\text { Ukraine }\end{array}$ & $\begin{array}{c}\text { The Times Higher Education World } \\
\text { University Rankings }\end{array}$ & QS World University Rankings \\
\hline $\begin{array}{l}\text { Kyiv (Ukraine's } \\
\text { Capital) }\end{array}$ & $\begin{array}{l}\text { - Taras Shevchenko NU of Kyiv } \\
(800-1001+) \\
\text { - NTU of Ukraine - Igor Sikorsky } \\
\text { Kyiv Polytechnic Institute (1001+) }\end{array}$ & $\begin{array}{l}\text { - Taras Shevchenko NU of Kyiv (411-420; 541-550) } \\
\text { - NTU of Ukraine - Igor Sikorsky Kyiv Polytechnic } \\
\text { Institute (501-550; 701-750) } \\
\text { - NU of Kyiv-Mohyla Academy }(1001+)\end{array}$ \\
\hline Donetsk region & - & - Vasyl Stus Donetsk NU (801-1000) \\
\hline Kharkiv region & $\begin{array}{l}\text { - V. N. Karazin Kharkiv NU } \\
(1001+)\end{array}$ & $\begin{array}{l}\text { - V. N. Karazin Kharkiv NU (401-410; 491) } \\
\text { - The NTU “Kharkiv Polytechnic Institute" (701-750; } \\
\text { 651-700) }\end{array}$ \\
\hline Lviv region & $\begin{array}{l}\text { - Ivan Franko NU of Lviv (1001+) } \\
\text { - Lviv Polytechnic NU (80-1001+) }\end{array}$ & - Lviv Polytechnic NU (751-800) \\
\hline Sumy region & - Sumy State University $(1001+)$ & - Sumy State University $(801-1000 ; 701-750)$ \\
\hline
\end{tabular}

Source: Quacquarelli Symonds [13]; Times Higher Education [18].

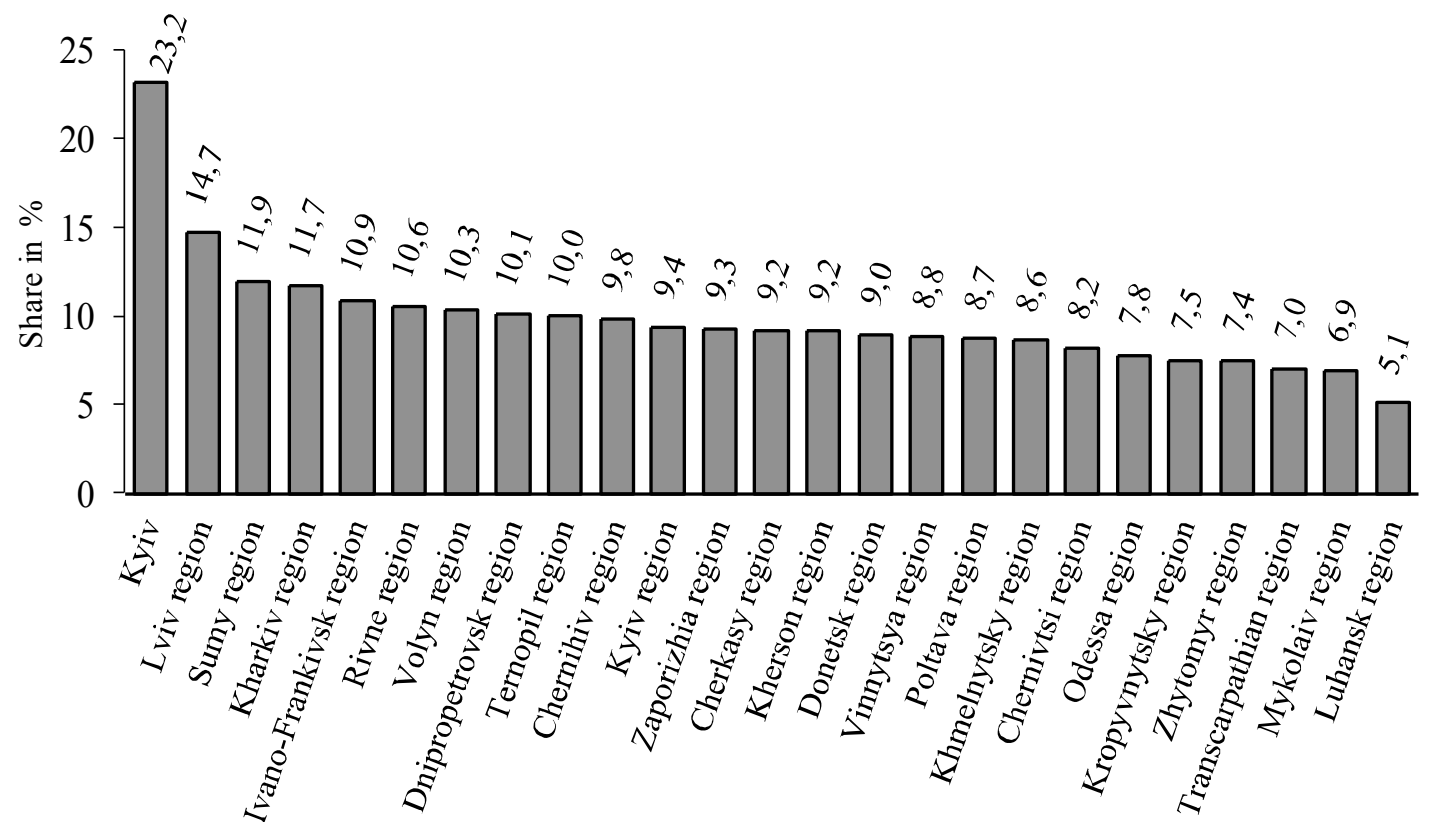

Fig. 2. Share of HEIs entrants with the score in math 180 or higher at the External Independent Testing Exam, \% (2019)

Source: calculated by the authors using [16, 19]. 
Priorities of improving the competitiveness of higher education in regional development management...

Only 8 of the 281 Ukrainian HEIs were ranked in the Times Higher Education World University Rankings and QS World University Rankings in 2018-2020. These universities represent only 5 of 26 Ukraine's regions. It should be noted that these regions had also the high quality indicators of secondary education of HIs entrants, in particular in mathematics, see Fig. 2.

The tendency of increasing imbalance in the number of entrants coming to the region for HE and leaving it is dangerous for balanced regional development. The donor regions that have the greatest loss of intellectual potential as a result of interregional and international migration (from $70 \%$ or more of potential students) include 13 regions (Fig. 3).

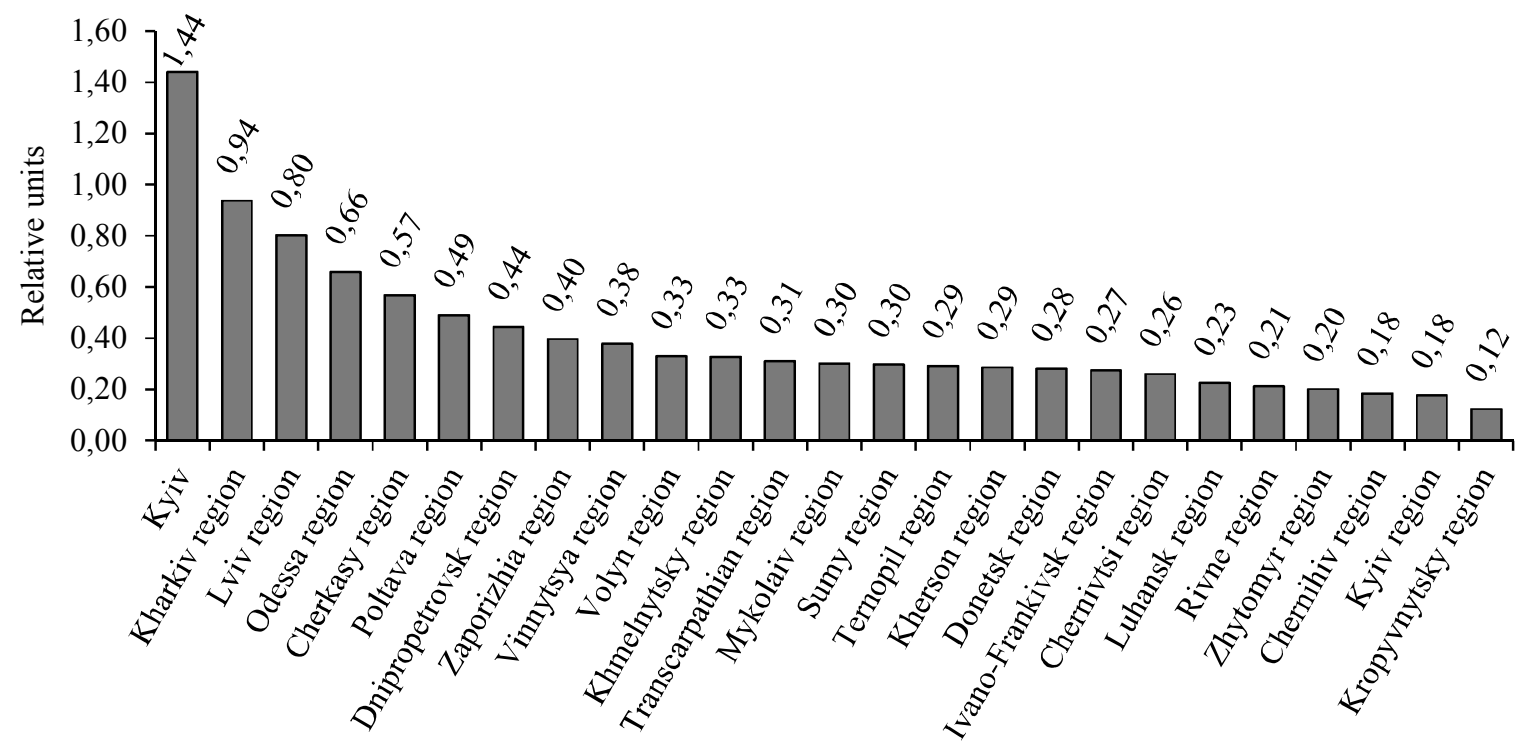

Fig. 3. Ratio of HEI entrants and high school graduates participating in the External Independent Testing Exam of this region (2019)

Source: calculated by the authors using [16, 19].

Taking into account the Global Sustainable Goals, the objectives determined in Ukraine's Regional Development Strategies as well as the results of the quality analysis of the HE systems in Ukraine's regions we propose the following priority areas for improving their competitiveness by the criterion "Quality" (Table 6).

Table 6

Priority areas for improving the competitiveness of HE systems in Ukraine's regions by the criterion "Quality"

\begin{tabular}{|c|c|c|}
\hline Priority areas & Regions of Ukraine & Target indicators \\
\hline 1 & 2 & 3 \\
\hline \multicolumn{3}{|c|}{ Entrants and students } \\
\hline $\begin{array}{l}\text { Increase in the attractiveness of } \\
\text { the region for higher education } \\
\text { entrants, reducing human losses } \\
\text { as a result of interregional } \\
\text { educational migration }\end{array}$ & $\begin{array}{l}\text { Kropyvnytskyi, Kyiv, Chernihiv, } \\
\text { Kherson, Zhytomyr, } \\
\text { Transcarpathian, Donetsk, Volyn, } \\
\text { Rivne, Vinnytsia, Khmelnytskyi, } \\
\text { Mykolaiv regions }\end{array}$ & $\begin{array}{c}\text { Ratio of HEI entrants and high } \\
\text { school graduates participating in } \\
\text { the External Independent Testing } \\
\text { Exam in this region }\end{array}$ \\
\hline $\begin{array}{c}\text { Increase in the attractiveness of } \\
\text { the region for international } \\
\text { students }\end{array}$ & $\begin{array}{l}\text { Dnipropetrovsk, Lviv, Odesa } \\
\text { regions, the city of Kyiv }\end{array}$ & Share of international students \\
\hline \multicolumn{3}{|c|}{ Lecturers and researchers } \\
\hline $\begin{array}{l}\text { Improving the academic } \\
\text { reputation of HEIs through } \\
\text { publications in editions indexed } \\
\text { in international scientometric } \\
\text { databases }\end{array}$ & $\begin{array}{l}\text { Kropyvnytskyi, Rivne, Kherson, } \\
\text { Mykolaiv, Khmelnytskyi, Chernihiv, } \\
\text { Zhytomyr, Poltava, Vinnytsia, } \\
\text { Ivano-Frankivsk, Cherkasy regions }\end{array}$ & $\begin{array}{l}\text { Number of works per } 100 \text { HEIs } \\
\text { lecturers and researchers in scien- } \\
\text { tific journals indexed in inter- } \\
\text { national scientometric databases } \\
\text { (Scopus, Web of Science, etc.) }\end{array}$ \\
\hline
\end{tabular}


Continuation of Table

\begin{tabular}{|c|c|c|}
\hline 1 & 2 & 3 \\
\hline \multicolumn{3}{|c|}{ HEI management } \\
\hline $\begin{array}{l}\text { Improving the academic } \\
\text { reputation of HEIs in national } \\
\text { rankings }\end{array}$ & $\begin{array}{c}\text { Chernihiv, Zhytomyr, Cherkasy, } \\
\text { Kherson, Volyn, Rivne, } \\
\text { Kropyvnytskyi, Poltava, } \\
\text { Zaporizhzhia, Khmelnytskyi, } \\
\text { Mykolaiv, Luhansk, } \\
\text { Transcarpathian, Ternopil, } \\
\text { Ivano-Frankivsk regions }\end{array}$ & $\begin{array}{l}\text { Region's HEI rating in the } \\
\text { National Academic Rating } \\
\text { "Top } 100 \text { Ukraine" }\end{array}$ \\
\hline $\begin{array}{l}\text { Improving the international } \\
\text { academic reputation of HEIs }\end{array}$ & $\begin{array}{l}\text { The city of Kyiv; Kharkiv, Lviv, } \\
\text { Dnipropetrovsk, Sumy, Odesa, } \\
\text { Chernivtsi, Vinnytsia, Donetsk, } \\
\text { Ivano-Frankivsk regions }\end{array}$ & $\begin{array}{l}\text { Number of region's HEIs and its } \\
\text { scores in the world university } \\
\text { rankings (e.g. The Times Higher } \\
\text { Education World University } \\
\text { Rankings; QS The World } \\
\text { University Rankings, etc.) }\end{array}$ \\
\hline $\begin{array}{c}\text { Enhancement of the region's } \\
\text { HEIs participation in } \\
\text { international educational } \\
\text { associations }\end{array}$ & $\begin{array}{l}\text { Kherson, Kropyvnytskyi, } \\
\text { Zaporizhzhia, Khmelnytskyi, Kyiv, } \\
\text { Lviv, Rivne, Zhytomyr regions }\end{array}$ & $\begin{array}{c}\text { Number of the region's HEIs - } \\
\text { participants of international } \\
\text { associations }\end{array}$ \\
\hline
\end{tabular}

Source: developed by the authors.

The monitoring of the HE system competitiveness in the Ukraine's regions by the criterion of social responsibility points out to the urgent problem of the low level of an access to HE by people with disabilities and other socially vulnerable population groups. The average share of HEIs students with disabilities in Ukraine does not exceed $1 \%$ (2019), whereas, for example, in Poland, this indicator is twice as high [3], Fig. 4.

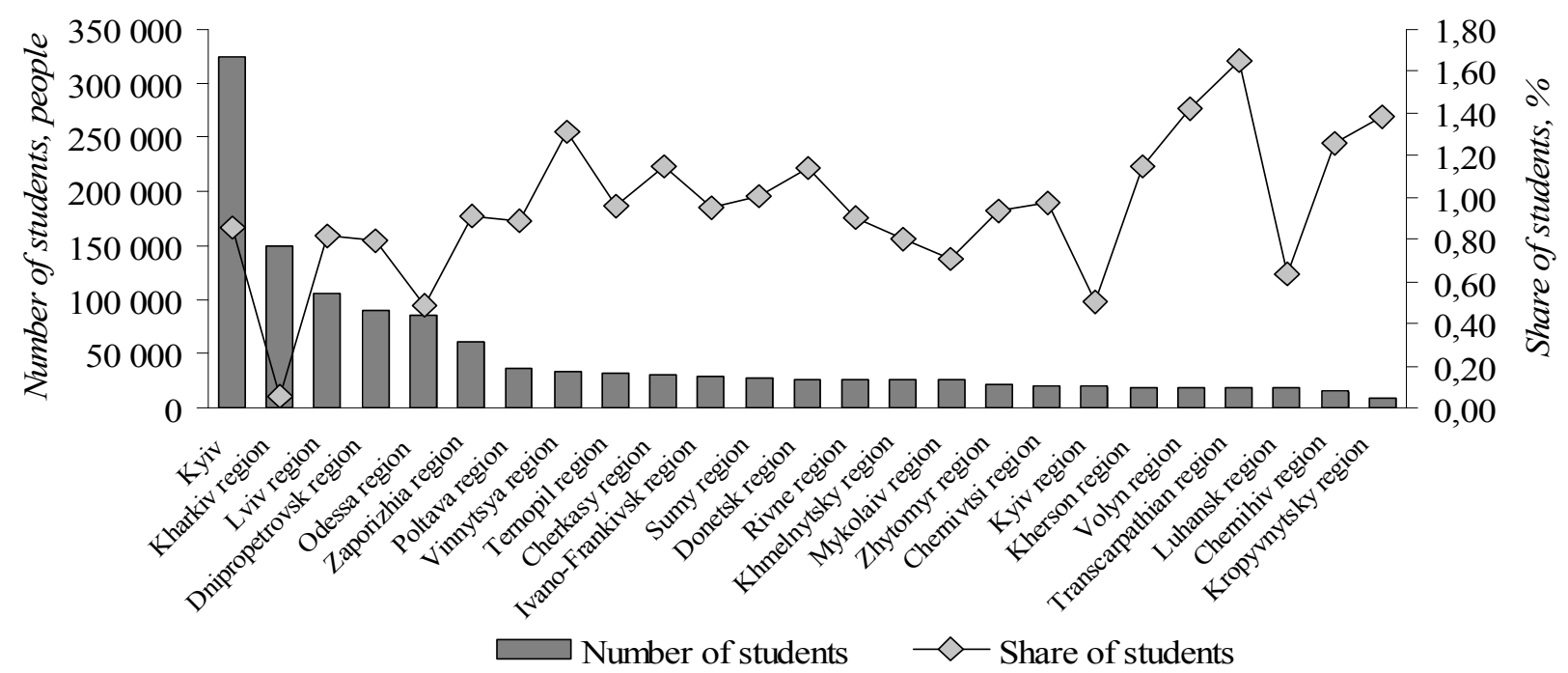

Fig. 4. Number and share of students with disabilities in HEIs (Ukraine's regions, 2019) Source: calculated by the authors using [16].

The significant differences in distribution of the Ukrainian regions by the financial support of HEIs are noticeable. The share of HEI students studying at the expense of local budgets confirms this conclusion (Fig. 5).

The priorities for enhancing the competitiveness of HE systems in Ukraine's regions by the criterion of social responsibility are defined in Table 7. 
Priorities of improving the competitiveness of higher education in regional development management...

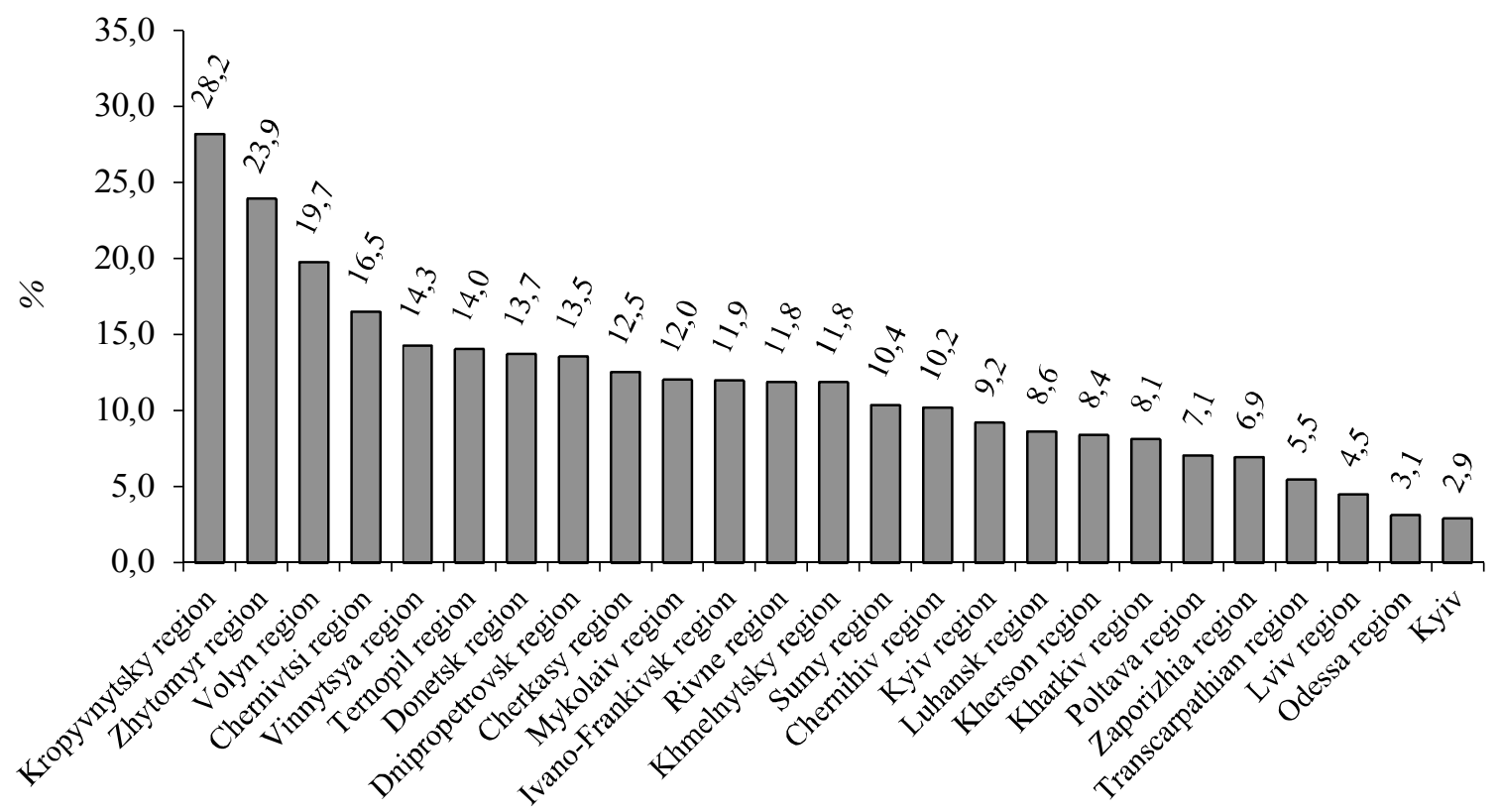

Fig. 5. Share of HEIs students studying at the expense of local budgets, \% (Ukraine's regions, 2019) Source: calculated by the authors using [16].

Priority areas for improving the competitiveness of HE systems in Ukraine's regions by the criterion "Social responsibility"

\begin{tabular}{|c|c|c|}
\hline Priority areas & Regions of Ukraine & Target indicators \\
\hline \multicolumn{3}{|c|}{ Entrants and students } \\
\hline $\begin{array}{l}\text { Increasing the accessibility of } \\
\text { higher education to people } \\
\text { with special educational needs }\end{array}$ & All the regions of Ukraine & $\begin{array}{l}\text { Number of students with } \\
\text { disabilities in HEIs } \\
\text { Share of students with } \\
\text { disabilities in HEIs }\end{array}$ \\
\hline $\begin{array}{l}\text { Increasing the level of } \\
\text { providing students with } \\
\text { dormitories and their quality }\end{array}$ & $\begin{array}{c}\text { Ivano-Frankivsk, Transcarpathian, Kherson, } \\
\text { Zaporizhzhia, Mykolaiv, Lviv, Poltava, } \\
\text { Vinnytsia, Donetsk, Cherkasy, } \\
\text { Kropyvnytskyi (Kirovohrad), Zhytomyr, } \\
\text { Chernihiv, Kyiv, Khmelnytskyi, Sumy, } \\
\text { Volyn, Dnipropetrovsk regions, } \\
\text { the city of Kyiv }\end{array}$ & $\begin{array}{l}\text { Level of the provision of HEI } \\
\text { students with dormitories }\end{array}$ \\
\hline \multicolumn{3}{|c|}{ Students, lecturers and researchers, HEI management } \\
\hline $\begin{array}{l}\text { Increasing the level of } \\
\text { academic integrity and } \\
\text { respecting the rights of } \\
\text { lecturers, researchers and } \\
\text { students }\end{array}$ & $\begin{array}{c}\text { Kherson, Rivne, Luhansk, Donetsk, Odesa } \\
\text { regions }\end{array}$ & $\begin{array}{l}\text { Number of the reported facts } \\
\text { about violations of the rights } \\
\text { of lecturers, researchers in } \\
\text { HEIs }\end{array}$ \\
\hline \multicolumn{3}{|c|}{ Regional authorities in higher education } \\
\hline $\begin{array}{l}\text { Increasing the role of local } \\
\text { authorities in shaping the } \\
\text { volume and structure of } \\
\text { training for regional } \\
\text { development needs }\end{array}$ & $\begin{array}{l}\text { Donetsk, Odesa, Transcarpathian, Kharkiv, } \\
\text { Lviv, Luhansk, Zaporizhzhia, Poltava, } \\
\text { Dnipropetrovsk regions, the city of Kyiv }\end{array}$ & $\begin{array}{c}\text { Share of students studying at } \\
\text { the expense of the local } \\
\text { budget, } \%\end{array}$ \\
\hline
\end{tabular}

Source: developed by the authors. 


\section{O. Hrynkevych, O. Sorochak}

The lack of statistical data on revenues and expenditures in HE at the regional level makes it difficult to analyze its competitiveness by the criterion of economic efficiency. By performance criterion in the economic efficiency analysis of HE systems, the regional distribution of patents for inventions and utility models per 100 researchers is the most disproportional. In most Ukraine's regions, the level of interconnection of research and innovative activity results remains low. This conclusion confirms the indicator of the number of innovative enterprises in the regions of Ukraine (Fig. 6).

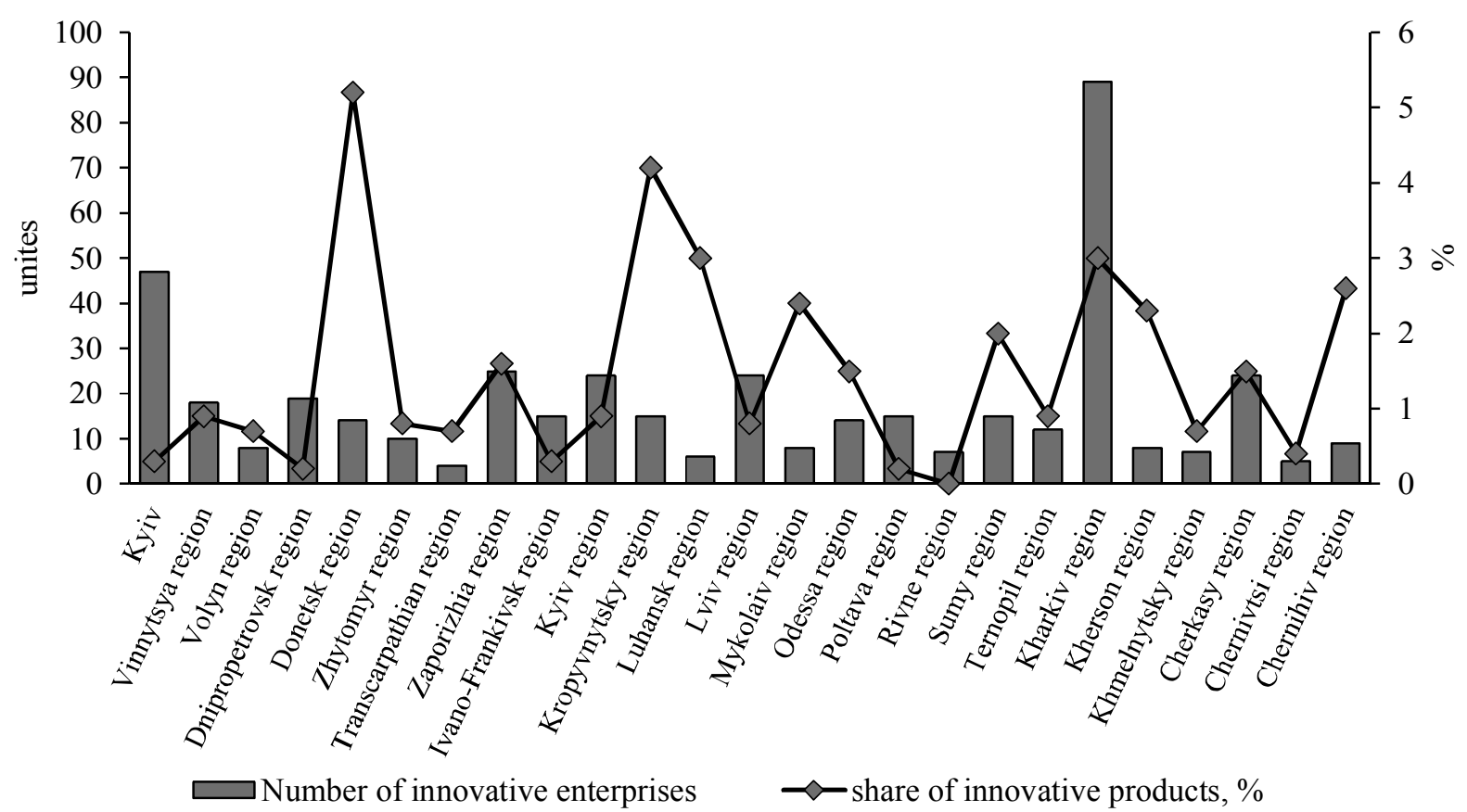

Fig. 6. Number of innovative enterprises and the share of innovative products in industry, \% (Ukraine's regions, 2019)

Source: calculated by the authors using [16].

The priority areas for enhancing the competitiveness of higher education systems in Ukraine's regions by the criterion of economic efficiency are identified in Table 8 .

Table 8

Priority areas for improving the competitiveness of HE systems in Ukraine's regions by the criterion "Economic efficiency"

\begin{tabular}{|c|c|c|}
\hline Priority areas & Regions of Ukraine & Target indicators \\
\hline 1 & 2 & 3 \\
\hline \multicolumn{3}{|c|}{ HEI graduates, employers } \\
\hline $\begin{array}{l}\text { Increasing the } \\
\text { employment rate of HEIs } \\
\text { graduates studied at the } \\
\text { expense of state and local } \\
\text { budgets }\end{array}$ & $\begin{array}{l}\text { Lviv, Ternopil, Transcarpathian, Chernihiv, } \\
\text { Donetsk, Cherkasy, Ivano-Frankivsk, } \\
\text { Kropyvnytskyi, Rivne, Kharkiv, Khmelnytskyi, } \\
\text { Dnipropetrovsk regions, the city of Kyiv }\end{array}$ & $\begin{array}{l}\text { Official employment rate of } \\
\text { graduates studied at the } \\
\text { expense of state and local } \\
\text { budgets, } \%\end{array}$ \\
\hline \multicolumn{3}{|c|}{ Lecturers and researchers, HEI management } \\
\hline $\begin{array}{l}\text { Increasing the } \\
\text { effectiveness of scientific } \\
\text { research }\end{array}$ & $\begin{array}{l}\text { Chernihiv, Sumy, Mykolaiv, Dnipropetrovsk, } \\
\text { Kharkiv, Volyn, Zaporizhzhia, Lviv, Kyiv, } \\
\text { Odesa, Transcarpathian, Zhytomyr, Cherkasy, } \\
\text { Kropyvnytskyi, Poltava, Kherson, Chernivtsi, } \\
\text { Ivano-Frankivsk regions, the city of Kyiv }\end{array}$ & $\begin{array}{l}\text { Number of patents for } \\
\text { inventions, utility models, } \\
\text { industrial designs per } 100 \\
\text { HEIs researchers }\end{array}$ \\
\hline
\end{tabular}


Priorities of improving the competitiveness of higher education in regional development management...

Continuation of Table

\begin{tabular}{|c|c|c|}
\hline 1 & 2 & 3 \\
\hline $\begin{array}{c}\text { Increase in the revenues } \\
\text { from R\&D in the region }\end{array}$ & All the regions of Ukraine & $\begin{array}{c}\text { Revenue share from scientific } \\
\text { activity in total revenues of } \\
\text { the region's HEIs }\end{array}$ \\
\hline \multicolumn{2}{|c|}{ HEI management, employers } \\
\hline $\begin{array}{c}\text { Increasing the level of } \\
\text { HEIs cooperation with } \\
\text { domestic and foreign } \\
\text { enterprises in innovative } \\
\text { activity }\end{array}$ & $\begin{array}{c}\text { Thanscarpathian, Chernivtsi, Poltava, } \\
\text { Ivano-Frankivs, Chernihiv, Vinnytsa, Donetsk, } \\
\text { Kropyvnytskyi, Kyiv, Zhytomyr, Odesa, } \\
\text { Zaporizhzhia, Ternopil, Lviv regions, } \\
\text { the city of Kyiv }\end{array}$ & $\begin{array}{c}\text { Share of enterprises that } \\
\text { cooperate with HEIs in } \\
\text { innovative activity, \% }\end{array}$ \\
\hline
\end{tabular}

Source: developed by the author.

\section{Conclusions}

Thus, the analysis of HE systems' competitiveness indicators in the regions of Ukraine points out significant imbalances in their development in terms of quality, social responsibility, and economic efficiency. For example, the high values of indicators of lecturers' academic reputation and researchers' level of entrants' preparation for the External Independent Testing Exam in the Lviv region ensure the quality criterion's leadership position. Whereas the low level of innovative activity in the region's industry, the problems of providing students with dormitories, the accessibility of higher education for socially vulnerable groups of the population, the low share of international students cause a decrease in the competitive position of the Lviv region among other regions of Ukraine.

According to the set of indicators used to estimate the HE system competitiveness of Ukraine's regions, the Top-10 leaders include Kyiv, Kharkiv, Lviv, Sumy, Chernivtsi, Dnipropetrovsk, Odesa, Poltava, Ivano-Frankivsk, Transcarpathian regions. These regions provide high indicators' values of the HEI academic ranking and a more excellent balance of educational, social, and economic indicators of competitiveness development.

The priority areas for improving the competitiveness of HE systems in Ukraine's regions, based on the proposed conceptual model and the correspondent analytical framework, can be used to design both national and regional strategies for enhancing the higher education system of Ukraine.

\section{Prospects for further research}

Areas for further research are related to analysing the consequences of the global pandemic impact on the HE system competitiveness in Ukraine at the macro-, meso- and micro-levels and their relationship.

1. Altbach P. (2014). Knowledge for the Contemporary University: Higher Education as a Field of Study and Training. In: Higher Education: A Worldwide Inventory of Research Centers, Academic Programs, and Journals and Publications. 3rd ed. Center for IHE, Boston College \& Lemmens Media, pp. 12-21.

2. Brint S., \& Clotfelter C. (2016). Higher Education Effectiveness. Journal of the Social Sciences, 2(1), pp. 2-37. doi: 10.1353/rus.2016.0008.

3. Central Statistical Office of Poland (2021). HEIs and Their Finances in 2019. Retrieved from: https://stat.gov.pl/en/databases/ (accessed 15 February 2021).

4. Długosz P. (2018). Integracja ukraińskich studentów podejmujących naukę w Polsce [Integration of Ukrainian students studying in Poland]. Review of Polish Diaspora, 2 (168), pp. 67-92.

5. International Organization for Standardization. (2010). ISO 26000:2010 (en). Guidance on social responsibility: Terms and definitions. Geneva: ISO.

6. International Organization for Standardization (2015). Quality management principles. Geneva: ISO. 


\title{
O. Hrynkevych, O. Sorochak
}

7. Grishnova O., \& Bekh S. (2014). Social'na vidpovidal'nist' universytetiv Ukrayiny': porivnyal'nyj analiz ta osnovni napryamy rozvytku [Social responsibility of Ukrainian universities: comparative analysis and main directions of development]. Bulletin of Taras Shevchenko National University of Kyiv. Economics, 158, pp. 11-18.

8. Hrynkevych O. et al. (2020). Competitiveness of Higher Education System as a Sector of Economy: Conceptual Model of Analysis with Application to Ukraine. Advances in Intelligent Systems and Computing, Vol. 1131. Springer, Cham.

9. Kisiołek A., Karyy O. and Halkiv L. (2021). The utilization of Internet marketing communication tools by higher education institutions (on the example of Poland and Ukraine), International Journal of Educational Management, Vol. ahead-of-print No. ahead-of-print. https://doi.org/10.1108/IJEM-07-2020-0345.

10. Matyukh S. (2013). Formuvannya kontseptualnykh zasad efektyvnosti diyalnosti vyshchykh navchalnykh zakladiv [The conceptual basics of efficiency formation in functioning of higher educational institutions]. Ekonomichnyy chasopys-XXI, 5-6, pp. 82-84.

11. McCowan T. (2016). Universities and the post-2015 development agenda: an analytical framework. Higher Education, 72(4), pp. 505-523.

12. Moyseyenko I, \& Hrynkevych O. (2018). Ekonomichna efektyvnist vyshchoyi osvity v Ukrayini [Economic efficiency of higher education in Ukraine]. Sotsialno-pravovi studiyi, 1, pp. 80-87. doi: 10.32518/2617-4162-2018-1-80-87.

13. Quacquarelli Symonds (2021). QS World University Rankings. Retrieved from: https://www. topuniversities.com/university-rankings (accessed 15 February 2021).

14. Shevchenko L. (2016). Universytetska osvita: ekonomichni priorytety ta upravlinnia rozvytkom : monohrafiia [University education, economic priorities and management development : monograph]. Kharkiv: Pravo, 188 p.

15. Teichler U. (2019). Steering in a Modern Higher Education System: The Need for Better Balances between Conflicting Needs and Expectations. Kessel: International Centre for Higher Education Research. doi: 10.17906/INCHER.0003.

16. The State Statistics Service of Ukraine. (2021). Statistical information. Retrieved from: http://www. ukrstat.gov.ua (accessed 12 February 2021).

17. The UNESCO Institute for Statistics. (2021). Education. International student mobility in tertiary education. Retrieved from: http://data.uis.unesco.org/Index.aspx\# (accessed 12 March 2021).

18. Times Higher Education (2021). World University Ranking 2018-2020. Retrieved from: https://www.timeshighereducation.com/world-university-rankings (accessed 10 March 2021).

19. Ukrainian Center for Educational Quality Assessment (2021). Statistical data of the external independent evaluation 2019. Retrieved from: https://zno.testportal.com.ua/stat (accessed 8 March 2021).

20. UNESCO (2021). Education 2030. Framework for Action Towards inclusive and equitable quality education and lifelong learning for all. Retrieved from: http://unesdoc.unesco.org/images/0023/002338/233813M.pdf (accessed 17 March 2021).

21. United Nations (2021). Sustainable Development Goals. Retrieved from: un.org/sustainabledevelopment (accessed 10 March 2021).

О. С. Гринькевич ${ }^{1}$, О. 3. Сорочак ${ }^{2}$

${ }^{1}$ Львівський національний університет імені Івана Франка,

${ }^{2}$ Національний університет “Львівська політехніка", кафедра менеджменту організацій

ORCID: ${ }^{1}$ 0000-0002-8646-8119, ${ }^{2} 0000-0003-2889-9284$

\section{ПРО ПРІОРИТЕТИ ПІДВИЩЕННЯ КОНКУРЕНТОСПРОМОЖНОСТІ ВИЩОЇ ОСВІТИ В УПРАВЛІННІ РЕГІОНАЛЬНИМ РОЗВИТКОМ (ПРИКЛАД УКРАЇНИ)}

\author{
(С) Гринькевич О. С., Сорочак О. 3., 2021
}

Мета статті - перевірити гіпотезу про істотність відмінностей у показниках розвитку регіональних систем вищої освіти в Україні та обгрунтувати пріоритетні напрями підвищення їх конкурентоспроможності за критеріями якості, соціальної відповідальності та економічної ефективності.

Автори обгрунтовують концептуальну модель для аналізу конкурентоспроможності системи вищої освіти за критеріями якості, економічної відповідальності та економічної ефективності, 
Priorities of improving the competitiveness of higher education in regional development management...

визначають перелік відповідних показників для їх вимірювання, а також пропонують результати аналізу систем вищої освіти в 25 регіонах України. Для дослідження використано основні положення теорій людського, соціального, інтелектуального капіталу, теорії стейкхолдерів, міждисциплінарний підхід, методи і показники статистичного аналізу.

Результати дослідження підтвердили гіпотезу про значні дисбаланси в розвитку регіональних систем вищої освіти в Україні, зокрема за такими показниками, як співвідношення абітурієнтів ЗВО та випускників середніх шкіл, які беруть участь у зовнішньому незалежному тестуванні в цьому регіоні, частка студентів, які навчаються за рахунок коштів місцевих бюджетів, кількість українських 3ВО у міжнародних рейтингах університетів. Зазначені дисбаланси спричиняють істотні стратегічні втрати людського та інтелектуального капіталу регіонів України, позначаються на їхньому інноваційному розвитку.

Практична значущість отриманих результатів полягає у тому, що запропоновано пріоритетні напрями підвищення конкурентоспроможності вищої освіти в регіонах України, які можуть бути використані для досягнення стратегічних цілей регіонального розвитку в частині реалізації інтелектуального потенціалу та підвищення конкурентоспроможності економіки.

Ключові слова: вища освіта; конкурентоспроможність; якість; соціальна відповідальність; економічна ефективність; регіон; Україна. 